\title{
Characterization of soil properties in relation to Shorea macrophylla growth performance under sandy soils at Sabal Forest Reserve, Sarawak, Malaysia
}

\author{
IZWAIDA CHE ADANAN", MOHD EFFENDI WASLI, MUGUNTHAN PERUMAL, HO SOO YING \\ Faculty of Resource Science and Technology, Universiti Malaysia Sarawak. 94300 Kota Samarahan, Sarawak, Malaysia. \\ Tel. +60-11-10959095, `email: izwaidacheadanan@gmail.com
}

Manuscript received: 16 December 2019. Revision accepted: 18 March 2020.

\begin{abstract}
Adanan IC, Wasli ME, Perumal M, Ying HS. 2020. Characterization of soil properties in relation to Shorea macrophylla growth performance under sandy soils at Sabal Forest Reserve, Sarawak, Malaysia. Biodiversitas 21: 1467-1475. A study was conducted in the Sabal Forest Reserve, Sarawak, to characterize soil properties in terms of soil morphological and physicochemical properties under sandy soil at the reforestation site in comparison with High Conservation Forest soil as well as to assess growth performance of planted $S$. macrophylla under the sandy soil. Study sites with the size of $25 \mathrm{~m} \times 25 \mathrm{~m}$ were established under reforestation sites (Early Establishment of Reforestation Site (ER) and Late Establishment of Reforestation Site (LR)) as well as the High Conservation Forests (HCF-1 and HCF-2). The results from soil morphological properties showed that the soils in ER and HCF-2 plots resemble Saratok series while soils in LR and HCF-1 plot were classified into Buso series. As for soil physicochemical properties, soil in all study sites were strongly acidic in nature with $\mathrm{pH}\left(\mathrm{H}_{2} \mathrm{O}\right)$ value less than 5.00 with sandy (more than 55\%) at both surface and subsurface soil. The survival percentage of planted S. macrophylla in ER and LR plot was $65 \%$ and $56 \%$, respectively. Long term monitoring on soil properties and growth performance of planted S.marophylla tree are essential in order to continuously provide information on the status of reforestation activity.
\end{abstract}

Keywords: Grey-White Podzolic soils, growth performance, Podzols soil, Shorea macrophylla

\section{INTRODUCTION}

The Heath Forest in Sarawak is known as "Kerangas" Forest, originating from an Iban word that refers to infertile soils (Brunig 1974). It is a seasonal lowland tropical rainforest that develops in dryland sites with predominantly podzolized, highly acidic and sandy soils (Brunig 1974; Ghazoul and Sheil 2010). Besides, sandy soils were recorded as least fertile compared to alluvial and sandstone forests (Dent et al. 2006). The free-draining sandy soils allow nutrients to leach readily (Katagiri et al. 1991; MacKinnon et al. 2013). Besides, heath forest soil also degraded quickly to bleached sand once the forest cover is removed making this type of forest extremely fragile. In addition, Jordan (1985) points out that the nutrient contents are in critical condition in the tropical rainforest and human impact influenced nutrient cycling. Moreover, heath forest is easily degraded by logging and burning and once degraded, heath forests develop into an open savannah of shrubs and trees. The disturbance such as forest fire would destroy the surface litter layer and root mat and take time to recover (Brunig 2016).

Therefore to combat soil degradation, a rehabilitation attempt was conducted at various types of degraded forest land. One of the promising methods to restore the degraded forestland was by adopting enrichment planting. Through enrichment planting, forest stands with uneven distribution of natural regeneration can be stocked as well as increase the soil fertility (Kobayashi 2004; Lamb et al. 2005; Keefe
2008). In enrichment planting, dipterocarps trees such as Shorea macrophylla (de Vriese) P.S. Ashton have been selected and widely planted in a reforestation program in Sarawak as it has fast-growing rate and endemic tree species to Borneo island. S. macrophylla or known as "Engkabang jantong" (Light Red Meranti) (in Malaysia) and "Tengkawang hantelok" (in Indonesia) is classified in the IUCN Red List of Threatened Species which if without proper conservation, could lead to its extinction in tropical rainforests (Utomo et al. 2018; Randi et al. 2019).

Various previous studies have been reported on the progress of reforestation activities to rehabilitate degraded areas at tropical region (Nik Muhamad et al. 1994; Suhaili et al. 1998; Norisada et al. 2005; Arifin et al. 2007, 2008a, 2008b; Hattori et al. 2013; Kenzo et al. 2014; Perumal et al. 2015, 2017a, 2017b). However, a recent study by Hattori et al. (2019) stated that long term monitoring of soil nutrient and biomass accumulation is rare in degraded tropical rainforest growing on sandy soil. In addition, relatively less information is known on the outcome of reforestation practice under sandy soil at degraded forest area via enrichment planting of $S$. macrophylla. Therefore, this study was conducted to characterize soil properties in terms of soil morphological and physicochemical properties under sandy soil at the reforestation site in comparison with High Conservation Forest soil and to assess the growth performance of planted S. macrophylla under sandy soil in reforestation sites. 


\section{MATERIALS AND METHODS}

\section{Study site}

This study was conducted from September 2014 to December 2017 in Sabal Forest Reserve (SFR), Sarawak, Malaysia (Figure 1).

The Sabal Forest Reserve has a total land area of 7,833 hectares and was gazetted in 1927. Sabal Forest Reserve consists of undulating and low lying lands in the north and steeper hill in the Klingkang range in the south which located $112 \mathrm{~km}$ southeast of Kuching and its elevation is about 100 to $150 \mathrm{~m}$ above sea level (Chai 1998; Hashim 2010). The mean annual rainfall is about $3585 \mathrm{~mm}$ while the mean annual temperature is $32.5^{\circ} \mathrm{C}$ with little variation throughout the year (Meteorological Department 2014). Based on the personal communication by the Forest Department officer, the previously Sabal area was implemented as a water catchment area located surrounding Sabal Forest Reserve area for more than 50 years by the local people and known as high conservation area (demarcated as HCF-1 and HCF-2). No major disturbance has been conducted at the high conservation forest.

However, some disturbance such as timber harvesting and shifting cultivation has been performed at some of the Sabal areas. Timber harvesting at the forest reserve started in 1970 but the local communities had encroached into the forest reserve and were practicing shifting cultivation as early as 1960 . Hence, since 1981 reforestation projects in the forest reserve were implemented by the Forest Department of Sarawak by planting indigenous species such as S. macrophylla. From 1981 to 1994, a total of 2,078 hectares of the land used for shifting cultivation had been reforested (Chai 1998). Out of the total area planted, S. macrophylla alone took up 720 hectares (Forest Department Sarawak 1995).

\section{Plot establishment at the study sites}

The study sites especially HCF-1 and HCF-2 were selected based on the in-situ observation (soil texture and soil color) during field sampling. Two reforestation sites planted with $S$. macrophylla with a spacing of $5 \mathrm{~m} \times 5 \mathrm{~m}$ were established, namely the Early Establishment of Reforestation Site (5 years) (ER) and Late Establishment of Reforestation Site (20 years) (LR). Two high conservation forests sites (50 years) namely High Conservation Forests 1 (HCF-1) and High Conservation Forests 2 (HCF-2) were selected in this study as a control. The plot with a size of 25 $\mathrm{m} \times 25 \mathrm{~m}$ was randomly demarcated at the study sites. Table 1 below shows the information on the plot size, GPS locations, number of planted S. macrophylla in $25 \mathrm{~m} \times 25$ $\mathrm{m}$ and number of plots established in ER, LR, HCF-1 and HCF-2 plots.

\section{Soil morphological properties assessment}

In order to characterize soil morphological properties, soil pit of approximately $100 \mathrm{~cm}$ depths were dug at each study site for soil profile description. The description was conducted according to the method proposed by the National Resources Conservation Service (NRCS) of the United States Department of Agriculture (USDA) (USDANRCS 2012). The in-situ observation was conducted in order to collect information on soil morphological properties such as color, texture, consistency, structure, rock fragment, organic matter and roots were distinguished. Soil color was determined by referring to the Munsell Soil Colour chart whereas the texture was determined by the "feel method". Additionally, soil hardness was measured and examined at each horizon by using the Yamanaka-type push cone penetrometer.

\section{Methods of soil physicochemical properties}

Soil samples were randomly collected at the depth of 0$10 \mathrm{~cm}$ (surface soil) and 30-40 cm (subsurface soil) by using soil auger at three random points and were mixed well to obtain a composite sample. For reforestation sites, the soils were mainly collected on the planting line while in $\mathrm{HCF}$, the soils were collected randomly. The soils were airdried and crushed to pass through a $2.0 \mathrm{~mm}$ and $0.425 \mathrm{~mm}$ mesh sieves for soil physicochemical analysis. The collected soil sample was stored in an airtight bag and labelled.

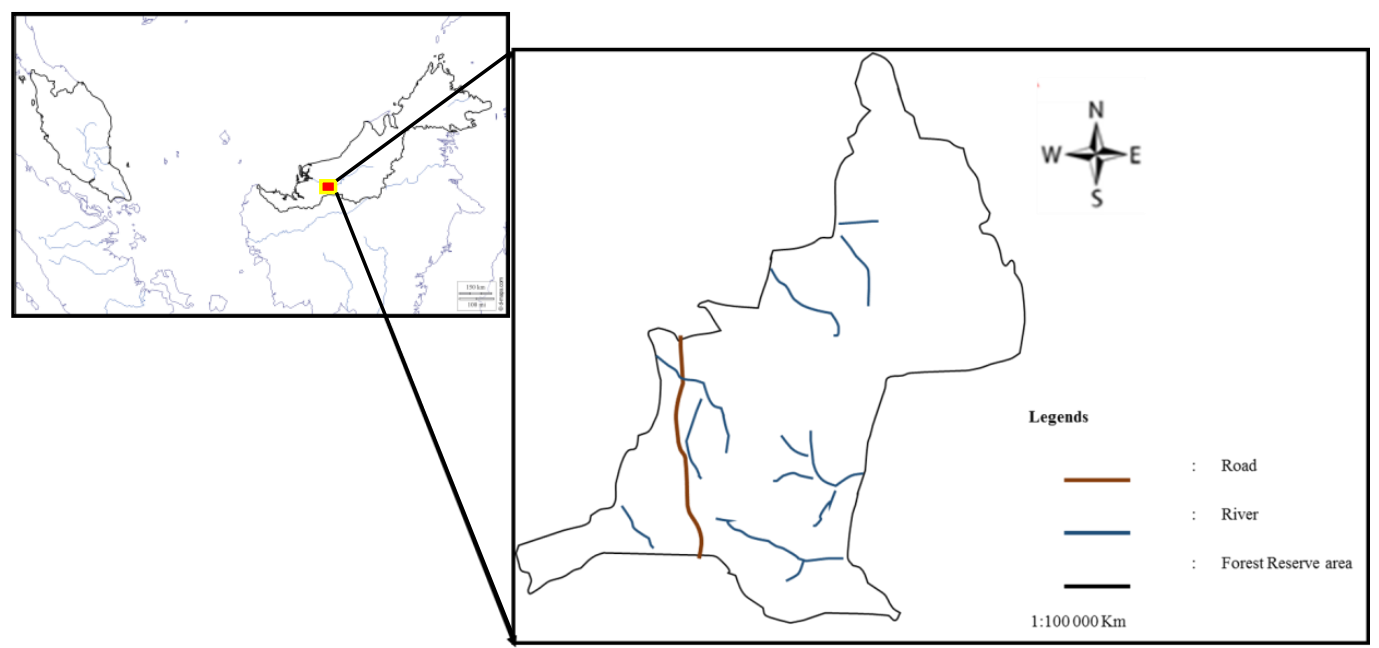

Figure 1. Map of study sites at Sabal Forest Reserve (SFR), Sarawak, Malaysia 
Table 1. The information on the study sites establishment in ER, LR, HCF-1, and HCF-2

\begin{tabular}{|c|c|c|c|c|}
\hline Plots & Plot size & GPS locations & $\begin{array}{l}\text { Number of planted } \\
\text { trees in } 25 \mathrm{~m} \times 25 \mathrm{~m}\end{array}$ & Number of plots \\
\hline ER & $25 \mathrm{~m} \times 25 \mathrm{~m}$ & $\mathrm{~N}^{\circ} 1^{\circ} 4{ }^{\prime} 41.57^{\prime \prime}, \mathrm{E} 110^{\circ} 55^{\prime} 50.78^{\prime \prime}$ & 25 & 6 \\
\hline LR & $25 \mathrm{~m} \times 25 \mathrm{~m}$ & N014'35.37', E110'55'35.02', & 25 & 4 \\
\hline HCF-1 & $25 \mathrm{mx} 25 \mathrm{~m}$ & N01 ${ }^{\circ} 5^{\prime} 52.12^{\prime \prime}$, E1 1056'31.19', & - & 3 \\
\hline $\mathrm{HCF}-2$ & $25 \mathrm{mx} 25 \mathrm{~m}$ & N01'5'54.04',, E11056'36.58', & - & 3 \\
\hline
\end{tabular}

Soil particle size analysis was determined through the pipette method to separate the inorganic soil particle into the sand, silt and clay fraction (Gee and Bauder 1986). The soil bulk density was measured on the undisturbed soil sample, collected at the reforestation sites and high conservation forest at the depth $0-10 \mathrm{~cm}$ and $30-40 \mathrm{~cm}$ using a $100 \mathrm{cc}$ core sampler with the ratio of the dry mass of soil to the bulk volume of soil core. Soil organic matter was measured using loss on ignition method (Dean Jr 1974). Soil $\mathrm{pH}$ was measured in distilled water and $1 \mathrm{M} \mathrm{KCl}$ in the soil to solution ratio of 1:5 using a glass electrode after reciprocal shaking for 1 hour at $120 \mathrm{rpm} / \mathrm{min}$. Exchangeable $\mathrm{Al}$ and $\mathrm{H}$ were determined by using filtrate from $\mathrm{pH} \mathrm{KCl}$ analysis. The filtrate from $\mathrm{pH} \mathrm{KCl}$ analysis will undergo the titration method with $0.01 \mathrm{M} \mathrm{NaOH}$ for exchangeable $\mathrm{H}$ and content of exchangeable $\mathrm{Al}$ with 0.01 $\mathrm{M} \mathrm{HCl}$. Electrical conductivity (EC) was measured before $\mathrm{pH}$ using a conductivity meter (Eutech Instrument- Cyberscan Con11) and using the supernatant at the soil to water ratio of 1:5. Total nitrogen (TN) was determined by the Kjeldahl acid-digestion method using concentrated sulphuric acid (Bremner and Mulvaney 1982). Loss on ignition method was used to measure Total Carbon (TC) in the soil (Dean Jr 1974). The content of exchangeable bases ( $\mathrm{Mg}, \mathrm{K}$ and $\mathrm{Ca}$ ) was extracted three times with $1 \mathrm{M}$ ammonium acetate at $\mathrm{pH} 7.0$ and the concentration of $\mathrm{Mg}, \mathrm{K}$ and $\mathrm{Ca}$ were determined with the atomic absorption spectrophotometry (Thermo Scientific, Ice Series 3500). After removing the excessive ammonium, the soil was extracted with $100 \mathrm{~g} \mathrm{~L}^{-1}$ $\mathrm{NaCl}$ solution and the supernatant was used to determine the Cation Exchange Capacity (CEC) using the titration method. Available Phosphorus was measured using Bray II method (Kuo 1996) where soil samples were extracted with an extracting solution, mixture of ammonium fluoride (1M $\left.\mathrm{NH}_{4} \mathrm{~F}\right)$ and hydrochloric acid $(0.5 \mathrm{M} \mathrm{HCl})$, then a colordeveloping reagent was added and the available phosphorus was determined by absorbance measurement with an Ultraviolet-visible (UV) spectrophotometer at a wavelength of $710 \mathrm{~nm}$ (JASCO V-630) (Bray and Kurtz 1945). All the analysis of soil physicochemical was performed at the Laboratory of Environmental Soil Science, Faculty of Resource Science and Technology, Universiti Malaysia Sarawak, Malaysia.

\section{Assessment of growth performance of planted Shorea macrophylla}

The diameter at breast height, tree height and survival percentage of planted S.macrophylla were assessed. The diameter tape was used to measure the Diameter at Breast Height (DBH) at $1.3 \mathrm{~m}$ above ground level. Suunto
Clinometer was used to measure the total height of the planted S. macrophylla. The formula to calculate MAID and MAIH of planted $S$. macrophylla were shown as below:

$$
\begin{aligned}
& \text { MAID }(\mathrm{cm} / \text { year })=\quad \frac{\text { Mean of Diameter at Breast Height }(\mathrm{DBH})}{\text { Age of the tree (year) }} \\
& \text { MAIH }(\mathrm{m} / \text { year })=\frac{\text { Mean of height }(\mathrm{m})}{\text { Age of tree }(\text { year })}
\end{aligned}
$$

The survival percentage of the planted S. macrophylla was calculated by using the formula as below:

$$
\mathbf{X}=\frac{\mathbf{Z}}{\mathbf{Y}} \times 100 \%
$$

Where:

$\mathrm{X}$ : Percentage of survival rate of $S$. macrophylla

Y: Total number of planted S. macrophylla

Z: Total number of planted $S$. macrophylla that is still survived

\section{Statistical analyses}

An independent sample t-test was used to compare the differences between the mean values for selected soil physicochemical properties in reforestation sites and High Conservation Forest. The Independent sample t-test was performed using excel. Multiple regression analysis was conducted to determine the dominant properties between soil total $\mathrm{C}$ and clay contents in contributing to soil CEC in the study sites.

\section{RESULTS AND DISCUSSION}

\section{Morphological properties of soil in the study sites at Sabal Forest Reserve}

In this study, the images of the soil profile at the Early Establishment of Reforestation Site (ER), Late Establishment of Reforestation Site (LR) and High Conservation Forest (HCF-1 and HCF-2) were shown in Figure 2, respectively. Meanwhile, Table 2 shows a detailed summary of the description and interpretation of the soil profile at each study site. Based on the in situ observation during field sampling, the reforestation area consisted of existing vegetation which derived after the previous land use was dominated by several woody pioneer species such as Macaranga spp., Ficus spp., Dillenia suffructicosa and light-demanding species such as Imperata cylindrica. 
ER

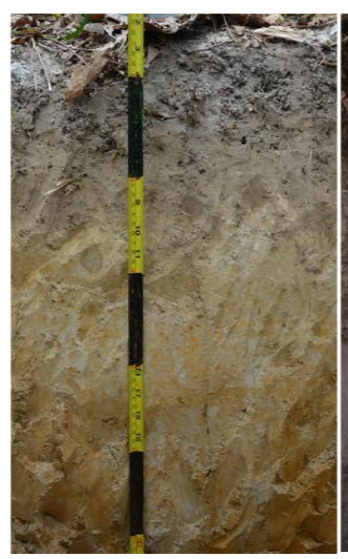

LR

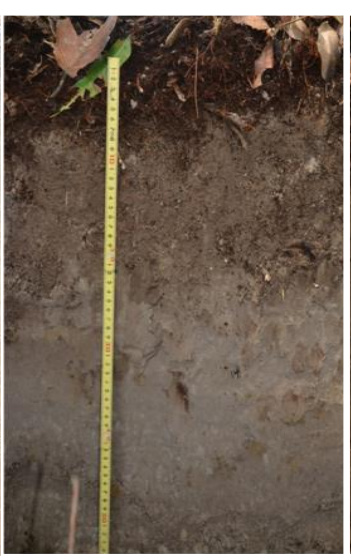

HCF-1

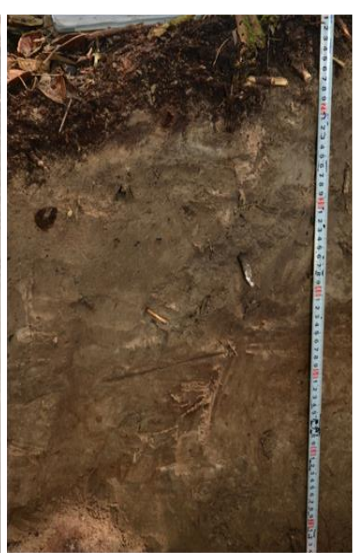

HCF-2

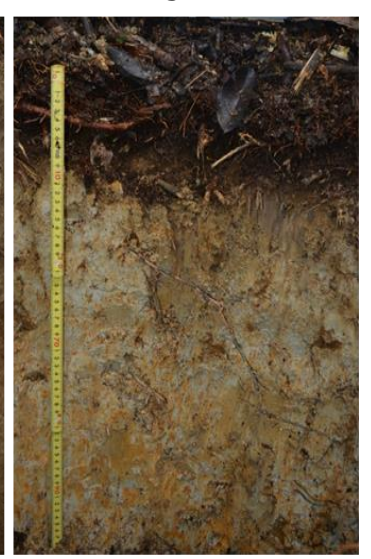

Figure 2. Soil profile at Early Establishment of Reforestation Site (ER), Late Establishment of Reforestation Site (LR) and High Conservation Forest (HCF-1 and HCF-2)

In terms of O layer, compared to ER plot $(\leq 3 \mathrm{~cm})$, the O layer at the LR, HCF-1 and HCF-2 plots was thicker $(\geq 3$ $\mathrm{cm})$. The $\mathrm{O}$ layer directly comes from accumulation and decomposition of litterfall from the accumulation and decomposition of litterfall from planted S. macrophylla and naturally grown pioneer tree species in the study sites that cover the topsoil. In addition, dense, well-developed root mat was seen in the plot of ER, LR, HCF-1, and HCF-2 with an abundance of roots with different sizes, varying from very few to many. However, only root mat in the High Conservation Forest (HCF-1 and HCF-2) plot can penetrate up to $50 \mathrm{~cm}$ into the subsurface layer. In contrast, root mat development and penetration were rather poor in ER and LR plots, mainly characterized by many to very few and coarse to very fine roots, up to $43 \mathrm{~cm}$ and $21 \mathrm{~cm}$ and absent towards the deeper soil profile. Based on the field observation, no root mats were found at the depth of more than $52 \mathrm{~cm}$ at HCF-1 due to the presence of rock fragment at the bottom of the soil profile which restricts the penetration of root in the soil. Besides, the ability of the root to penetrate to deeper soil depth was influenced by the soil hardness.

The surface horizons showed a mixture of eluvial (bleached sand) deposits with A horizon giving rise to EA or $\mathrm{AE}$ horizon, with respect to the dominance of $\mathrm{A}$ or $\mathrm{E}$ features of the pedons, ranged from $3 \mathrm{~cm}$ to $52 \mathrm{~cm}$ at all study sites except for the case of HCF-2 plot. In ER, LR and $\mathrm{HCF}-1$ plot, E horizon, including E1 and E2 horizon, varies in terms of depth between $13 \mathrm{~cm}$ and $60 \mathrm{~cm}$, generally characterized by the sandy loam or loamy sand soil texture.

Based on the in-situ observation, the soil profile color in LR and HCF-1 plots were darker than in ER and HCF-2 plots. Based on Table 2 the color of the mixture of EA or AE horizon was usually darker, ranging from dark brown (7.5YR3/1), brown (7.5YR4/4) and yellowish-brown (10YR5/3) in ER, LR, and HCF-1, respectively. This might due to the continuous supply of fresh organic materials in the form of litterfall contributed to the darker color of the surface and subsurface horizon. Meanwhile, the spodic E horizon is pale in color, characterized by yellow (10YR7/6), light brownish-grey (7.5YR5/1) and light grey (7.5YR7/1) ER, LR and HCF-1 plots.
Soil texture class in ER and $\mathrm{HCF}-2$ plots was classified within sandy clay loam to sandy loam and the soil texture in LR and HCF-1 plots fall within the class of sandy loam or loamy sand based on the "feel" method. This indicates that parent materials at the study site mainly consisted of sandstone and sandy shale. In contrast, the soil structure of the soil profile in LR and $\mathrm{HCF}-1$ plots were weak to moderate sub-angular in blocky and soil profiles in ER and HCF-2 plots were shown moderate to the strong subangular blocky structure as moving down of the soil profiles. In addition, no consistency in soil was observed in LR and HCF-1 plots as moving down the soil profile as compared to ER and HCF-2 plots. This indicates that the soil in LR and HCF-1 plots were very sandy than in ER and HCF-2 plots.

Therefore, judging from the soil texture, soil consistency, soil structure, soil color and the presence of a spodic horizon, the soil at the study sites was classified as shown in Table 3.

In Sabal Forest Reserve, the Saratok series was formed mainly on the low undulating hill and strongly dissected erosion surface of the Sabal Forest Reserve. Besides, the Grey-White Podzolic soils group in ER and HCF-2 were identified by the existence of contrasting soil texture between $40 \mathrm{~cm}$ soil depth. Soil Survey Staff (1966) reported that Grey-White Podzolic soils have pale in color with weak to strong subangular blocky. This Grey-White Podzolic soil group corresponds to Typic Paleaquults of Ultisols, according to the USDA Soil Taxonomy (Soil Survey Staff 2014).

The main differences for Podzols were the presence of weakly cemented to non-cemented of spodic ( $\mathrm{E}$ horizon) and albic horizon discovered within $100 \mathrm{~cm}$ from the surface. Other features were soil texture in LR and HCF-1 which ranging from sandy loam to loamy sand with soil color ranged from light grey (7.5YR7/1) to very dark grey (7.7YR3/1) and dark brown (10YR4/3). Hence, weak to moderate of subangular blocky structure with no consistency of soil were form. Podzols soil group under Sarawak soil classification is tentatively correlated with Typic Haplothods of Spodosols under USDA Soil Taxonomy (Teng 2004; Soil Survey Staff 2014). 
Table 2. Summary on the soil morphological properties at ER, LR, HCF-1, and HCF-2 at Sabal Forest Reserve, Sarawak, Malaysia

\begin{tabular}{|c|c|c|c|c|c|c|c|c|c|c|c|}
\hline Plot & Horizon & Depth $(\mathrm{cm})$ & Colour & Textures $^{\text {a) }}$ & Structure $^{\text {b) }}$ & Consistency $^{\mathrm{c}}$ & $\operatorname{Roots}^{\text {d) }}$ & Boundary ${ }^{\mathrm{e}}$ & $\begin{array}{c}\text { Rock } \\
\left.\text { (ragment }{ }^{\mathrm{f}}\right)\end{array}$ & $\mathrm{OM}^{\mathrm{g})}$ & $\begin{array}{c}\text { Hardnes } \\
(\mathbf{m m})^{\mathbf{h})}\end{array}$ \\
\hline \multirow{5}{*}{$\overline{\text { ER }}$} & $\left(\mathrm{N} 1^{\circ} 4^{\prime}\right.$ & $1.57^{\prime \prime}$, E110 & 5' 50.78") & & & & & & & & \\
\hline & $\mathrm{O}$ & $0-3$ & Root mat a & dd litterfall & & & & & & & \\
\hline & $\mathrm{AE}$ & $3-19$ & 10YR5/3 & SL & $1-2 / \mathrm{n} / \mathrm{sbk}$ & ss/sp & f-c/ma-fe & $\mathrm{cw}$ & $\mathrm{n}$ & $\mathrm{m}$ & 18 \\
\hline & E & $19-43$ & 10YR7/6 & SL & $2 / \mathrm{n} / \mathrm{sbk}$ & $\mathrm{ss} / \mathrm{sp}$ & vf/vfe & c-gw & $\mathrm{n}$ & 1 & 24 \\
\hline & B & $43-100$ & 10YR6/8 & SCL & $2 / \mathrm{n} / \mathrm{sbk}$ & $s-v s / p$ & $\mathrm{n}$ & c-gw & $\mathrm{n}$ & 1 & 21 \\
\hline
\end{tabular}

LR $\quad\left(\mathrm{N} 1^{\circ} 4^{\prime} 35.37^{\prime \prime}, \mathrm{E} 110^{\circ} 55^{\prime} 35.02^{\prime \prime}\right)$

$\mathrm{O} \quad 0-7 \quad$ Root mat and litterfall

$\begin{array}{lcccccccccc}\text { AE } & 7-13 & 7.5 Y R 3 / 1 & \text { SL } & 2 / n / s b k & \text { ns/np } & \text { f-me/fe-ma } & \text { ds } & \mathrm{n} & \mathrm{h} & 12 \\ \text { E1 } & 13-21 & 7.5 Y R 5 / 1 & \text { LS } & 2 / \mathrm{n} / \mathrm{sbk} & \mathrm{ns} / \mathrm{np} & \mathrm{vf}-\mathrm{f} / \mathrm{fe} & \mathrm{cs} & \mathrm{n} & \mathrm{m} & 12 \\ \mathrm{E} 2 & 21-60 & 7.5 \mathrm{YR} 7 / 1 & \mathrm{LS} & 1 / \mathrm{n} / \mathrm{sbk} & \mathrm{ns} / \mathrm{np} & \mathrm{n} & \mathrm{cs} & \mathrm{n} & 1 & 20\end{array}$

HCF-1 (N1 ${ }^{\circ} 5^{\prime} 54.04 "$, E110 56' 36.58")

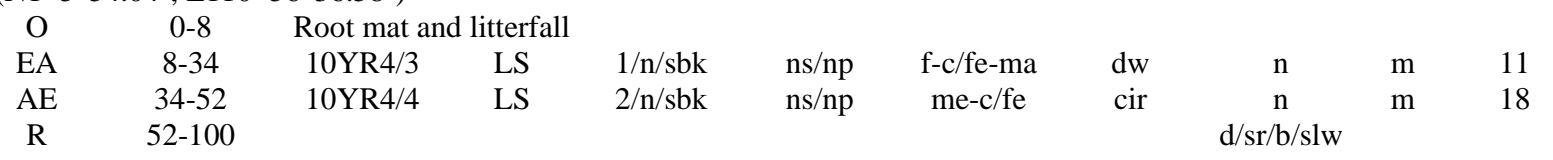

HCF-2 (N1 ${ }^{\circ} 5^{\prime} 52.12 "$, E110 $\left.56^{\prime} 31.19^{\prime \prime}\right)$

\begin{tabular}{ccccccccccc}
$\mathrm{O}$ & $0-11$ & \multicolumn{2}{c}{ Root mat and litterfall } & & & & & & & \\
$\mathrm{AB}$ & $11-26$ & $10 \mathrm{YR} 6 / 4$ & $\mathrm{SCL}$ & $2 / \mathrm{n} / \mathrm{sbk}$ & $\mathrm{s} / \mathrm{sp}$ & $\mathrm{me}-\mathrm{c} / \mathrm{fe}$ & $\mathrm{cw}$ & $\mathrm{n}$ & 1 & 17 \\
$\mathrm{~B} 1$ & $26-44$ & $10 \mathrm{YR} 7 / 4$ & $\mathrm{SL}$ & $2-3 / \mathrm{n} / \mathrm{sbk}$ & $\mathrm{s} / \mathrm{p}$ & $\mathrm{me}-\mathrm{c} / \mathrm{fe}$ & $\mathrm{dw}$ & $\mathrm{n}$ & 1 & 18 \\
$\mathrm{~B} 2$ & $44-60$ & $10 \mathrm{YR} 6 / 6$ & SCL & $3 / \mathrm{n} / \mathrm{sbk}$ & $\mathrm{s} / \mathrm{p}$ & $\mathrm{vf-f} / \mathrm{n}-\mathrm{fe}$ & $\mathrm{dw}$ & $\mathrm{n}$ & 1 & 14 \\
\hline
\end{tabular}

Note: a) Field Texture: SL: Sandy Loam, SCL: Sandy Clay Loam, LS: Loamy Sand, b) Soil Structure: 1: weak, 2: medium, 3: strong, Size: n:none, Type: sbk: sub angular blocky, c) Consistency: ns: non-sticky, s: sticky, ss: slightly sticky, vs: very sticky, np: non-plastic, p: plastic, sp: slightly plastic, d) Root size and abundant: vf: very fine, f: fine, me: medium, c: coarse, vfe: very few, fe: few, co: common, ma: many, n: none, e) Boundary: c: clear, g: gradual, d: diffuse, s: smooth, ir: irregular, w: wavy, f) Rock fragment abundant, shape, size and weathering: f: few, d: dominant, sr: sub rounded, b: boulder, slw: slightly weathered, n: none, g) Organic matter (OM): l: low, m: medium h: high. h) Hardness.

Table 3. Soil classification for ER, LR, HCF-1 and HCF-2 plots at the study sites, Sabal Forest Reserve, Sarawak, Malaysia

\begin{tabular}{|c|c|c|c|}
\hline \multirow[t]{2}{*}{ Plots } & \multicolumn{2}{|c|}{$\begin{array}{c}\text { Sarawak Soil Classification System } \\
\text { (Teng 2004) }\end{array}$} & \multirow{2}{*}{$\begin{array}{c}\begin{array}{c}\text { USDA Soil Taxonomy Classification System } \\
\text { (Soil Survey Staff 2014) }\end{array} \\
\text { Soil order } \\
\end{array}$} \\
\hline & Soil series & Soil group & \\
\hline ER & Saratok & Grey-White Podzolic & Ultisols \\
\hline LR & Buso & Podzols & Spodosols \\
\hline $\mathrm{HCF}-1$ & Buso & Podzols & Spodosols \\
\hline $\mathrm{HCF}-2$ & Saratok & Grey-White Podzolic & Ultisols \\
\hline
\end{tabular}

\section{Soil physicochemical properties at the study sites}

Soil properties under Grey White Podzolics soil

The result on the soil physicochemical properties under Grey White Podzolic soils at ER and HCF-2 plot were shown in Table 4. Generally, soils at the study sites were strongly acidic with high contents of exchangeable $\mathrm{Al}$ and low contents of exchangeable bases. The parameters indicating soil acidity ( $\mathrm{pH}$ and exchangeable $\mathrm{Al}$ ) and cation retention capacity (CEC and ECEC) at surface and subsurface soils were higher in the HCF-2 than in the ER. The sand content in both ER and HCF-2 plots were ranging from $56 \%$ to $80 \%$ at the surface and subsurface soils. Only sand content at the subsurface soil showed significant differences. The surface and subsurface soil showed significantly lower clay content which was less than $30 \%$. Clay content in HCF-2 was significantly higher than the ER at both surface and subsurface soils.
Across the study sites, no correlation was observed between TC and clay contents in both the surface soils and subsurface soils: $r=-0.174$ and $r=-0.054$, respectively. In addition, based on multiple regression analysis, no correlation between CEC values with total carbon or clay content $\left(\mathrm{CEC}=0.271 \mathrm{TC}+0.585\right.$ Clay, $\left.\mathrm{r}^{2}=0.360\right)$ at the surface soil and clay content was found as the dominant contributor of soil $\mathrm{CEC}$ with the equation $\mathrm{CEC}=0.258 \mathrm{TC}$ +0.589 Clay $^{* *}, \mathrm{r}^{2}=0.782$ at the subsurface soil. The fact that the CEC was higher as compared to the Effective Cation Exchange Capacity (ECEC) suggested the possible occurrence of some variable negative charges (Boonyanuphap et al. 2007; Tanaka et al. 2009). Since the ECEC values were much lower than the CEC values, permanent negative charges of clay minerals were predominant under acidic conditions. Judging from the small difference between soil CEC and ECEC, the 
contribution of negative charges from soil organic matter to the cation retention capacity might be small (Arifin et al. 2008a). There was no large variation among ER and HCF-2 plots for total carbon, total nitrogen or clay contents, although the clay content was significantly higher in the HCF-2 plot than in ER plot. It is noteworthy that the negative charge derived from organic matter and clay contents is regarded as an important factor for nutrient retention capacity and probably influences the fertility status of the soils to a certain extent (Hamzah et al. 2009). Hattori et al. (2013) mentioned that relatively high levels of permanent negative charge derived from clay content and inclination prevent a substantial loss of soil nutrient by leaching.

\section{Soil properties under Podzols soil}

The results on the soil physicochemical properties under Podzols soil at the LR and HCF-1 plot were shown in Table 5. The soils both at LR and HCF-1 plots were very sandy (more than $80 \%$ sand content) and low in CEC and nutrient content. The $\mathrm{pH}$ value in the HCF-1 was higher than LR at the surface soil and no significant difference at the subsurface soil. The content of exchangeable bases in HCF-1 plot was higher at both surface and subsurface soil, although, HCF-1 showed higher sand content as compared to LR at both surface and subsurface soils.

In the present study, the correlation was only observed between TC and clay contents in the subsurface soils $r=$ $0.681^{*}$ ( $p>0.05$ ), respectively. However, based on multiple regression analysis, no correlation were found between CEC value with both clay content and total carbon in the surface soil $\left(\mathrm{CEC}=0.594 \mathrm{TC}+0.066\right.$ Clay $\left(\mathrm{r}^{2}=\right.$ $0.420)$ ) and in the subsurface soil $(\mathrm{CEC}=-0.479 \mathrm{TC}+$ 1.009 Clay $\left.\left(r^{2}=0.443\right)\right)$. These indicate that the soil in the study sites was extremely sandy with low cation retention capacity. As stated by Katagiri et al. (1991), sandstone parent material and low clay content influenced the poor nutrient retention in sand soil as nutrients were easily leached from all layers of the soil. Besides, Katagiri et al. (1991) also reported that the number of nutrients was very low under sandy soils of heath forests resulted from the low supply of organic matter returned by litterfall and the rapid decomposition caused by high temperature. Thus, the dissolved nutrients were stored within the thick litterfall $(O$ horizon) and root mat layer before the nutrients were leached into the spodic E horizon (Kendawang et al. 2004). Hattori et al. (2019) further reported that the removal and destruction of the thick layer of litterfall and root mat may accelerate the leaching process of nutrients and limiting the recovery of the secondary forest under sandy soils. Under the LR plot, the previous forest disturbance might influence the development of the root mats and slightly thin $\mathrm{O}$ horizon as compared to the HCF-1 plot. Besides, root mat in the LR plot only accumulate at the surface soil and penetrate up to $21 \mathrm{~cm}$ soil depth as compared to root mat in HCF-1 plot that could penetrate up to $52 \mathrm{~cm}$. TC and TN are typically higher in unburned Kerangas forest (Kendawang et al. 2004) because thick root mats cover the infertile sandy soil and help to retain nutrients. However, in this study, TC and TN in the HCF-1 plot were lower as compared to the LR plot. This might be due to the leached out or absorbed by existing tree species in the study site.

Table 4. Selected soil physicochemical properties under enrichment planting at Early Establishment of the Reforestation Site (ER) and High Conservation Forest 2 (HCF-2) plots under Grey-White Podzolic soils (Ultisols)

\begin{tabular}{|c|c|c|c|c|c|c|c|c|}
\hline \multirow{3}{*}{ Parameters } & & \multirow{2}{*}{$\begin{array}{c}\text { ER } \\
n=6\end{array}$} & \multirow{2}{*}{\multicolumn{2}{|c|}{$\begin{array}{c}\text { HCF-2 } \\
n=3\end{array}$}} & \multirow{2}{*}{\multicolumn{2}{|c|}{$\begin{array}{c}\text { ER } \\
n=6\end{array}$}} & \multicolumn{2}{|c|}{ HCF-2 } \\
\hline & & & & & & & \multicolumn{2}{|c|}{$\mathbf{n}=\mathbf{3}$} \\
\hline & & \multicolumn{3}{|c|}{ Surface soil: 0-10cm } & \multicolumn{4}{|c|}{ Subsurface soil: $30-40 \mathrm{~cm}$} \\
\hline $\mathrm{pH}-\mathrm{H}_{2} \mathrm{O}$ & & $4.44 \pm 0.22$ & $4.34=$ & \pm 0.19 & 4.73 & \pm 0.15 & $4.65=$ & 0.09 \\
\hline $\mathrm{EC}^{\mathrm{a}}$ & $\mu \mathrm{S} \mathrm{cm} \mathrm{cm}^{-1}$ & $29.7 \pm 3.0$ & $33.7=$ & \pm 6.1 & 10.6 & \pm 1.9 & $13.3=$ & 2.8 \\
\hline Total Carbon & $\mathrm{g} \mathrm{kg}^{-1}$ & $26.8 \pm 3.2$ & $20.4=$ & \pm 8.1 & 12.7 & \pm 1.2 & $12.8=$ & 0.6 \\
\hline Total Nitrogen & $\mathrm{g} \mathrm{kg}^{-1}$ & $1.6 \pm 0.2$ & $1.1=$ & \pm 0.5 & 0.3 & \pm 0.1 & $0.2=$ & $0.1 * *$ \\
\hline $\mathrm{C}: \mathrm{N}^{\mathrm{b}}$ & & $17.3 \pm 0.8$ & $18.8=$ & \pm 1.1 & 39.1 & \pm 10.3 & $75.3=$ & 23.6 \\
\hline $\mathrm{CEC}^{\mathrm{c}}$ & $\mathrm{cmol}_{\mathrm{ckg}}{ }^{-1}$ & $6.7 \pm 2.0$ & $8.3=$ & \pm 0.5 & 5.2 & \pm 1.8 & $7.5=$ & $0.6^{* *}$ \\
\hline Exch. Ca & $\mathrm{cmol}_{\mathrm{ckg}}{ }^{-1}$ & $0.31 \pm 0.07$ & $0.61=$ & $\pm 0.03^{*}$ & 0.18 & \pm 0.02 & $0.44=$ & $0.09 * *$ \\
\hline Exch. K & $\mathrm{cmol}_{\mathrm{ckg}}{ }^{-1}$ & $0.26 \pm 0.24$ & $0.18=$ & \pm 0.03 & 0.04 & \pm 0.03 & $0.08=$ & 0.01 \\
\hline Exch. Mg & $\mathrm{cmol}_{\mathrm{ckg}}{ }^{-1}$ & $0.15 \pm 0.05$ & $0.19=$ & \pm 0.05 & 0.09 & \pm 0.07 & $0.07=$ & 0.02 \\
\hline Exch. Al & $\mathrm{cmol}_{\mathrm{C}} \mathrm{kg}^{-1}$ & $1.36 \pm 0.79$ & $2.54=$ & $\pm 0.24 *$ & 1.62 & \pm 0.53 & $3.09=$ & $0.28 *$ \\
\hline Sum of bases & $\mathrm{cmol}_{\mathrm{C}} \mathrm{kg}^{-1}$ & $0.83 \pm 0.29$ & $1.17=$ & $\pm 0.11 * *$ & 0.36 & \pm 0.13 & $0.75=$ & $0.10^{*}$ \\
\hline $\mathrm{ECEC}^{\mathrm{d}}$ & $\mathrm{cmol}_{\mathrm{ckg}}{ }^{-1}$ & $2.18 \pm 1.02$ & $3.70=$ & $\pm 0.33^{*}$ & 2.14 & \pm 0.59 & $3.84=$ & $0.24 *$ \\
\hline Base Saturation & $\%$ & $12.7 \pm 4.2$ & $14.1=$ & \pm 0.7 & 7.4 & \pm 3.2 & $10.2=$ & 2.2 \\
\hline Available P & $\mathrm{mg} \mathrm{kg}^{-1}$ & $8.5 \pm 1.7$ & $6.4=$ & \pm 1.4 & 2.8 & \pm 1.5 & $3.0=$ & 0.7 \\
\hline Al Saturation & $\%$ & $59.4 \pm 10.1$ & $68.5=$ & \pm 1.9 & 81.3 & \pm 5.7 & $80.4=$ & 3.1 \\
\hline Clay & $\%$ & $9.3 \pm 2.8$ & $21.8=$ & $\pm 5.2 * *$ & 16.5 & \pm 4.7 & $27.9=$ & $0.3^{*}$ \\
\hline Silt & $\%$ & $18.5 \pm 3.6$ & $10.7=$ & $\pm 1.3^{*}$ & 16.7 & \pm 4.0 & $14.3=$ & 1.7 \\
\hline Sand & $\%$ & $72.2 \pm 4.8$ & $67.5=$ & \pm 3.9 & 66.8 & \pm 5.2 & $57.8=$ & $1.8^{*}$ \\
\hline Bulk density & $\mathrm{g} \mathrm{mL}^{-1}$ & $1.03 \pm 0.22$ & $1.21=$ & \pm 0.17 & 1.46 & \pm 0.12 & $1.46=$ & 0.09 \\
\hline
\end{tabular}

Mean \pm standard deviation, n: number of plot, aEC: Electrical Conductivity, bC: N: Carbon to Nitrogen, cCEC: Cation Exchange Capacity, dECEC: Effective CEC. The symbol $*$ and $* *$ indicate significant differences at $\mathrm{p}<0.05$ and $\mathrm{p}<0.01$, respectively (t-test). 
Table 5. Selected soil physicochemical properties under enrichment planting at Late Establishment of the Reforestation Site (LR) and High Conservation Forest 1 (HCF-1) plots under Podzols soil (Spodosols)

\begin{tabular}{|c|c|c|c|c|c|c|c|c|c|c|c|c|c|}
\hline \multirow[t]{2}{*}{ Parameters } & & $\begin{array}{c}\text { LR } \\
n=4\end{array}$ & & urfac & \multicolumn{3}{|c|}{$\begin{array}{c}\text { HCF-1 } \\
n=3\end{array}$} & \multicolumn{3}{|c|}{$\begin{array}{c}\text { LR } \\
n=4\end{array}$} & \multicolumn{3}{|c|}{$\begin{array}{c}\text { HCF-1 } \\
n=3\end{array}$} \\
\hline & & 4.07 & \pm & 0.13 & 4.44 & \pm & $0.17 * *$ & 4.58 & \pm & 0.24 & 4.58 & \pm & 0.08 \\
\hline $\mathrm{EC}^{\mathrm{a}}$ & $\mu \mathrm{Scm}^{-1}$ & 40.2 & \pm & 6.1 & 31.1 & \pm & 6.6 & 16.9 & \pm & 4.0 & 14.2 & \pm & 1.4 \\
\hline Total Carbon & $\mathrm{gkg}^{-1}$ & 21.7 & \pm & 5.5 & 17.2 & \pm & 3.4 & 10.8 & \pm & 4.1 & 8.2 & \pm & 2.4 \\
\hline Total Nitrogen & $\mathrm{gkg}^{-1}$ & 0.8 & \pm & 0.3 & 0.7 & \pm & 0.1 & 0.3 & \pm & 0.2 & 0.3 & \pm & 0.1 \\
\hline $\mathrm{C}: \mathrm{N}^{\mathrm{b}}$ & & 30.2 & \pm & 13.2 & 23.6 & \pm & 6.3 & 49.5 & \pm & 31.2 & 34.9 & \pm & 17.5 \\
\hline Exch. Ca & $\mathrm{cmol}_{\mathrm{ckg}}{ }^{-1}$ & 0.54 & \pm & 0.13 & 0.7 & \pm & 0.15 & 0.60 & \pm & 0.13 & 0.52 & \pm & 0.03 \\
\hline Exch. K & $\mathrm{cmol}_{\mathrm{ckg}}{ }^{-1}$ & 0.04 & \pm & 0.01 & 0.06 & \pm & 0.04 & 0.01 & \pm & 0.01 & 0.04 & \pm & $0.01 * *$ \\
\hline Exch. Mg & $\mathrm{cmol}_{\mathrm{ckg}} \mathrm{kg}^{-1}$ & 0.17 & \pm & 0.09 & 0.18 & \pm & 0.08 & 0.10 & \pm & 0.01 & 0.07 & \pm & 0.04 \\
\hline Exch. Al & $\mathrm{cmol}_{\mathrm{ckg}}{ }^{-1}$ & 0.46 & \pm & 0.18 & 0.49 & \pm & 0.26 & 0.55 & \pm & 0.18 & 0.60 & \pm & 0.46 \\
\hline Sum of bases & $\mathrm{cmol}_{\mathrm{ckg}} \mathrm{kg}^{-1}$ & 0.85 & \pm & 0.25 & 1.09 & \pm & 0.28 & 0.87 & \pm & 0.18 & 0.80 & \pm & 0.12 \\
\hline $\mathrm{ECEC}^{\mathrm{d}}$ & $\mathrm{cmol}_{\mathrm{ckg}} \mathrm{kg}^{-1}$ & 1.30 & \pm & 0.31 & 1.59 & \pm & 0.24 & 1.42 & \pm & 0.05 & 1.41 & \pm & 0.43 \\
\hline Base Saturation & $\%$ & 19.4 & \pm & 3.1 & 28.7 & \pm & $6.1 * *$ & 49.7 & \pm & 19.4 & 37.1 & \pm & 11.8 \\
\hline Al Saturation & $\%$ & 34.6 & \pm & 10.3 & 30.9 & \pm & 14.2 & 38.8 & \pm & 13.0 & 39.5 & \pm & 17.8 \\
\hline Clay & $\%$ & 7.2 & \pm & 2.7 & 5.4 & \pm & 1.6 & 9.4 & \pm & 3.8 & 8.7 & \pm & 5.0 \\
\hline Silt & $\%$ & 11.1 & \pm & 0.8 & 9.9 & \pm & 2.2 & 9.7 & \pm & 1.9 & 8.3 & \pm & 2.1 \\
\hline Sand & $\%$ & 81.6 & \pm & 2.4 & 84.8 & \pm & 3.5 & 80.9 & \pm & 3.9 & 83.0 & \pm & 6.2 \\
\hline Bulk Density & $\mathrm{gmL}^{-1}$ & 1.31 & \pm & 0.11 & 1.17 & \pm & 0.16 & 1.48 & \pm & 0.09 & 1.47 & \pm & 0.15 \\
\hline
\end{tabular}

Mean \pm standard deviation: $\mathrm{n}$ : number of plot, ${ }^{\mathrm{a}} \mathrm{EC}$ : Electrical Conductivity, ${ }^{\mathrm{b}} \mathrm{C}: \mathrm{N}$ : Carbon to Nitrogen, ${ }^{\mathrm{c}} \mathrm{CEC}$ : Cation Exchange Capacity, ${ }^{\mathrm{d}} \mathrm{ECEC}$ : Effective CEC. The symbol $*$ and $* *$ indicate significant differences at $\mathrm{p}<0.05$ and $\mathrm{p}<0.01$, respectively (t-test).

Table 6. The growth performance of planted Shorea macrophylla in the present study and other previous studies on reforestation in Sarawak, Malaysia

\begin{tabular}{ccccccccc}
\hline Species & Plot & $\begin{array}{c}\text { Age stands } \\
(\text { Years })\end{array}$ & $\begin{array}{c}\text { Planting } \\
\text { technique }\end{array}$ & $\begin{array}{c}\text { Survival } \\
(\boldsymbol{\%})\end{array}$ & $\begin{array}{c}\text { MAIH } \\
\left(\text { myear }^{-1}\right)\end{array}$ & $\begin{array}{c}\text { MAID } \\
\left(\text { cmyear }^{-1}\right)\end{array}$ & Soil order & Sources \\
\hline S. macrophylla & ER & 5 & LP & 65 & 0.48 & 0.35 & Ultisols & Present study \\
S. macrophylla & LR & 20 & LP & 56 & 0.50 & 0.82 & Spodosols & Present study \\
& & & & & & & & \\
S. macrophylla & SM99 & 15 & LP & 57 & 0.58 & 0.44 & Ultisols & Perumal et al. 2017b \\
S. macrophylla & SM98 & 16 & LP & 82 & 0.52 & 0.44 & Ultisols & Perumal et al. 2017b \\
S. macrophylla & SM97 & 17 & LP & 80 & 0.51 & 0.55 & Ultisols & Perumal et al. 2017b \\
S. macrophylla & SM96 & 18 & LP & 88 & 0.65 & 0.82 & Ultisols & Perumal et al. 2017b \\
\hline
\end{tabular}

Note: SM99: S. macrophylla planted in the year 1999 at Sampadi Forest Reserve, SM98: S. macrophylla planted in the year 1998 at Sampadi Forest Reserve, SM97: S. macrophylla planted in the year 1997 at Sampadi Forest Reserve, SM96: S. macrophylla planted in the year 1996 at Sampadi Forest Reserve, *Planting technique: LP, Line Planting

\section{Survivorship of planted Shorea macrophylla under sandy soil}

Table 6 shows the growth performance of planted $S$. macrophylla in the present study and other previous studies on reforestation in Sarawak.

In the current study, the survival percentage, MAIH, and MAID of the planted S. macrophylla in ER plot were lower as compared to a previous study conducted by Perumal et al. (2017b) excepted for SM99. The survival percentage and MAIH of planted S. macrophylla in the LR plot were lower as compared to other previous studies. Meanwhile, MAID of the planted S.macrophylla in the LR plot was similar to planted S.macrophylla in SM96. Based on the present study the soil at the study sites can be classified as sandy, meanwhile, the finding on the soil at the previous study (Sampadi Forest Reserve) was annually flooding. However, based on the results in the present study and previous study by Perumal et al. (2017b), the planted S. macrophylla still can survive under harsh conditions. Although, the previous study by Turner et al. (2000) found that high sand content and low water retention capacity in the forest soils led to brief periods of the severe soil-water deficit, which in turn limited plant growth. The study conducted by Tanaka et al. (2014) at Sabal Forest Reserve reported that infertile sandy soil in Sabal influences the shortness of trees in Sabal. The severe disturbance by fire that occurs at the start of shifting cultivation destroys the surface litter layer and root mat, which accelerates nutrient loss and in turn limit trees regrowth in degraded forests on sandy soil (Brunig 2016).

Besides sandy soil, competition between the existing pioneer species, light intensity, soil fertility, nutrients and water holding capacity, as well as a topographical feature, also might contribute to the growth performance of the 
planted S. macrophylla in the study sites. According to Perumal et al. (2017b), the high density of pioneer species could be assumed to be another reason why most of the growth performance of planted of $S$. macrophylla was poor. Based on the in situ observation, study sites were surrounded by varies types of pioneer tree species that grow between the planting line. In the ER plot, several existing pioneer species were higher in terms of height than planted $S$. macrophylla. Therefore, the planted $S$. macrophylla in the ER plot may have acclimated to compete with the existing pioneer trees species for light, minerals, and water. However, those pioneer species can provide the shade for the planted $S$. macrophylla in the ER plot as $S$. macrophylla is well known as shade-tolerant species at the seedling stage.

Therefore, based on this study, it is suggested that further study on the vegetation survey, especially under reforestation sites, should be performed to get detail information on the species distribution at the reforestation site and the high conservation forest under the same soil condition. Nonetheless, long-term monitoring of the soil, as well as the growth performance of the planted $S$. macrophylla in the planting site, is required.

\section{ACKNOWLEDGEMENTS}

This study was funded and supported by the JapanMalaysia Association (JMA). The authors wish to express gratitude to the Director and staff of the Forest Department of Sarawak for permission and support during this study. The authors also would like to thank local villager especially Mr. Ekin and his family for their kindness and assistance during the fieldwork.

\section{REFERENCES}

Arifin A, Tanaka S, Jusop S, Ibrahim Z, Hattori D, Majid NM, Sakurai K 2007. Soil characteristics under the rehabilitation of degraded forestland in Perak, Peninsular Malaysia. Jpn Soc Pedol 51: 76-86.

Arifin A, Tanaka S, Jusop S, Ibrahim Z, Hattori D, Majid NM, Sakurai K. 2008a. Assessment on soil fertility status and growth performance of planted dipterocarp species in Perak, Peninsular Malaysia. J Appl Sci 8: 3795-3805.

Arifin A, Tanaka S, Jusop S, Ibrahim Z, Hattori D, Majid NM, Sakurai K. 2008b. Rehabilitation of degraded tropical rainforest in Peninsula Malaysia with a multi-storied plantation technique of indigenous dipterocarp species. Jpn J For Environ 50 (2): 141-152.

Boonyanuphap J, Sakurai K, Tanaka S. 2007. Soil nutrient status under upland farming practice in the Lower Northern Thailand. Tropics 16 (3): 215-231

Bray RH, Kurtz LT. 1945. Determination of total, organic, and available forms of phosphorus in soils. Soil Sci 59 (1): 39-46.

Bremner JM, Mulvaney CS. 1982. Nitrogen total. In: Page AL, Mille RH, Keeney DR. (eds) Methods of Soil Analysis Part 2: Chemical and Microbiological Properties. American Society of Agronomy and Soil Science Society of America, Madison, WI, USA.

Brunig EF. 1974. Ecological Studies in the Kerangas forests of Sarawak and Brunei. Forest Department, Sarawak, Malaysia.

Brunig EF. 2016. Conservation and management of Tropical rainforests: An Integrated Approach to Sustainability ( $2^{\text {nd }}$ ed.). Boston: CAB International.

Chai EOK. 1998. Aspect of a Tree Improvement Programme for Shorea macrophylla (de Vriese) Ashton in Sarawak, Malaysia. [Dissertation]. University of Edinburg, Edinburg, UK.
Dean Jr WE. 1974. Determination of carbonate and organic matter in calcareous sediments and sedimentary rocks by loss on ignition, comparison with other methods. SEPM J Sedimentary Petrol 44: 242248.

Dent DH, Bagchi R, Robinson D, Majalap-Lee N, Burslem DFRP. 2006. Nutrient fluxes via litterfall and leaf litter decomposition vary across a gradient of soil nutrient supply in a lowland tropical rain forest. Plant Soil 288: 197-215.

Forest Department Sarawak. 1995. Brief Notes on Reforestation and Agroforestry Projects at Sabal Forest Reserve. Forest Department, Sarawak, Malaysia.

Gee GW, Bauder JW. 1986. Particle-size analysis. In: Klute A. (ed.) Methods of Soil Analysis. Part 1: Physical and Mineralogical Methods. American Society of Agronomy and Soil Science Society of America, Madison, WI, USA.

Ghazoul J, Sheil D. 2010. Tropical Rain Forest Ecology, Diversity, and Conservation. Oxford University Press, New York.

Hamzah MZ, Arifin A, Zaidey AK, Azirim AN, Zahari I, Hazandy AH, Affendy H, Wasli ME, Shamsuddin J, Muhamad MN. 2009. Characterizing soil nutrient status and growth performance of planted dipterocarp and non-dipterocarp species on degraded forest land in Peninsular Malaysia. J Appl Sci 9: 4125-4223.

Hashim NR. 2010. Analyzing long-term landscape changes in a Borneo Forest Reserve using aerial photographs. Open Geogr J 3: 161-169.

Hattori D, Kenzo T, Yamauchi N, Irino KO, Kendawang JJ, Ninomiya I, Sakurai K. 2013. Effects of environmental factors on growth and mortality of Parashorea macrophylla (Dipterocarpaceae) planted on slopes and valleys in a degraded tropical secondary forest in Sarawak, Malaysia. Soil Sci Plant Nutr 59 (2): 218-228.

Hattori D, Kenzo T, Shirahama T, Harada Y, Kendawang JJ, Ninomiya I, Sakurai K. 2019. Degradation of soil nutrients and slow recovery of biomass following shifting cultivation in the heath forests of Sarawak, Malaysia. For Ecol Manag 432: 467-477.

Jordan CF. 1985. Nutrient Cycling in Tropical Forest Ecosystems. John Wiley \& Sons, Chichester.

Katagiri S, Yamakura T, Sen HL. 1991. Properties of soil in Kerangas Forest on sandstone at Bako National Park, Sarawak, East Malaysia. Southeast Asian Stud 29 (1): 35-47.

Keefe KJ. 2008. Enrichment planting of native tree species in the eastern Amazon of Brazil; silvicultural, financial and household assessments. [Dissertation]. University of Florida, Miami, FL.

Kendawang JJ, Tanaka S, Ishihara J, Shibata K, Sabang J, Ninomiya I, Ishizuka S, Sakurai K. 2004. Effects of shifting cultivation on soil ecosystems in Sarawak, Malaysia: slash and burning at Balai Ringin and Sabal Experimental Sites and effect on soil organic matter. Soil Sci Plant Nutr 50 (5): 677-687.

Kenzo T, Furutani R, Hattori D, Tanaka S, Sakurai K, Ninomya I, Kendawang JJ. 2014. Aboveground and belowground biomass in logged-over tropical rain forests under different soil conditions in Borneo. J For Res 20 (1): 197-205.

Kobayashi S. 2004. Landscape rehabilitation of degraded tropical forest ecosystems: Case study of the CIFOR/Japan project in Indonesia and Peru. For Ecol Manag 201: 13-22.

Kuo S. 1996. Phosphorus: In Method of Soil Analysis, Part 3, Chemical Methods. In: Sparks DL, Page AL, Helmke P, Leoppert RH. (eds.). Soil Science Society of America and American Society of Agronomy, Madison, WI, USA.

Lamb D, Erskine PD, Parrotta JA. 2005. Restoration of degraded tropical forest landscape. Science 310: 1628-1632.

MacKinnon K, Hatta G, Halim H, Mangalik A. 2013. The Ecology of Kalimantan: Indonesian Borneo. Volume III. Tuttle Publishing, NY, USA.

Meteorological Department. 2014. Weather Data (2004-2013). Kuching, Sarawak, Malaysia.

Nik Muhamad M, Azizah H, Idris A. 1994. Rehabilitation of ex-tin mining land by agroforestry practice. J Trop For Sci 71: 123-127.

Norisada M, Hitusma G, Kuroda K, Yamanoshita T, Masumori M, Tange T, Yagi H, Nuyim T, Sasaki S, Kojima K. 2005. Acacia mangium, a nurse tree candidate for reforestation on degraded sandy soils in the Malay Peninsula. For Sci 5: 498-510.

Perumal M, Wasli ME, Ho SY, Lat J, Sani H. 2015. Soil morphological and physicochemical properties at reforestation sites after enrichment planting of Shorea macrophylla in Sampadi Forest Reserve, Sarawak, Malaysia. Borneo J ResourSci Technol 5: 28-43.

Perumal M, Wasli ME, Ho SY, Lat J, Sani H. 2017a. Association between soil fertility and growth performance of planted Shorea macrophylla 
(de Vriese) after enrichment planting at rehabilitation sites of Sampadi forest reserve, Sarawak, Malaysia. Int J For Res 2017: 1-16.

Perumal M, Wasli ME, Ho SY, Lat J, Sani H. 2017b. Survivorship and growth performance of Shorea macrophylla (de Vriese) afte enrichment planting for reforestation purposes at Sarawak, Malaysia. Online J Biol Sci 17 (1): 7-17.

Randi A, Julia S, Kusumadewi Y, Robiansyah I, Shomat F, Tanggaraju S, Hamidi A, Juiling S, Bodos V, Maryan, A. 2019. Shorea macrophylla The IUCN Red List of Threatened Species 2019. e.T33620A125629642. https://dx.doi.org/10.2305/IUCN.UK.20193.RLTS.T33620A125629642.en. Downloaded on 24 February 2020

Soil Survey Staff. 1966. A classification of Sarawak soils. Technical Paper No. 2. Department of Agricultural Sarawak, Kuching, Sarawak, Malaysia.

Soil Survey Staff. 2014. Keys to Soil Taxonomy (12 $2^{\text {th }}$ ed.). United States Department of Agriculture, Natural Resource Conservation Service, Washington, DC, USA

Suhaili R, Majid NM, Hamzah MZ, Paudyal BK. 1998. Initial growth performance of indigenous timber species by open planting technique on degraded forest land. Malaysian For 61: 232-242.

Syuhada AB, Shamsuddin J, Fauziah CI, Arifin A, Rosenani AB. 2014 Formation and characteristics of Spodosols formed on Sandstone in the Extremely High Rainfall area of Sarawak, Malaysia. Asian J Agric Food Sci 2: 115-128.

Tanaka S, Tachibe S, Wasli ME, Lat J, Seman L, Kendawang JJ, Iwasaki K, Sakurai K. 2009. Soil characteristics under cash crop farming in upland areas of Sarawak, Malaysia. AgricEcosyst Environ 129: 293301.

Tanaka S, Wasli ME, Kendawang JJ, Sakurai K. 2014. The impacts of alteration in agriculture on the environment and ecosystem in Sarawak, Malaysia. Kuroshio Sci 8: 7-14.

Teng SC. 2004. Keys to soil classification of Sarawak. Agriculture Department of Sarawak, Malaysia.

Turner IM, Lucas PW, Becker P, Wong SC, Yong WH, Choong MF, Tyree MT. 2000. Tree leaf form in Brunei: a heath forest and a mixed dipterocarp forest compared. Biotropica 32 (1): 53-61.

USDA-NRCS. 2012. Field book for describing and sampling soils, Version 3.0. In: Schoeneberger PJ, Wysocki DA, Benham EC, Broderson WD. (eds) Natural Resources Conservation Service. National Soil Survey Center, Lincoln, NE.

Utomo S, Uchiyama S, Ueno S, Matsumoto A, Widiyatno, Indrioko S, Na'iem M, Tsumura Y. 2018. Effects of Pleistocene climate change on genetic structure and diversity of Shorea macrophylla in Kalimantan rainforest. Tree Gen Genomes 14 (4): 44. 